\title{
Pertumbuhan dan produksi Okra merah (Abelmoschus esculentus L. Moench) pada dosis pupuk kompos serasah yang berbeda dan pemangkasan
}

\author{
(Growth and production of red Okra (Abelmoschus esculentus L. Moench) at doses of leaf \\ compost fertilizer and pruning)
}

\author{
R. N. Habiba, W. Slamet, dan E. Fuskhah \\ Agroecotechnology, Faculty of Animal and Agricultural Sciences, Diponegoro University \\ Tembalang Campus, Semarang 50275 - Indonesia \\ CorrespondingE-mail : rifnanurhabiba@gmail.com
}

\begin{abstract}
The research aims was to investigate the interaction between dose of leaf compost and pruning on the growth and production of red okra. The research was assigned in basic design of completely randomized $4 \times 2$ factorial with three replications. The first factor was doses of leaf $K(0,50,100,150 \mathrm{~kg}$ $\mathrm{N} / \mathrm{ha}$ ). The second factor was pruning $\mathrm{P}$ (unpruned and pruned), each treatment was repeated three times. The parameters measured were stem diameter, number of leaves, number of fruits per plant, number of fruit per plot, and fruit weight per plot,. The data were analyzed statistically by of variance followed by Duncan's Multiple Range Test (DMRT). The results showed that there was no interaction effect at treatment doses of compost litter and pruning. Dosage of compost litter of $50 \mathrm{~kg} \mathrm{~N} / \mathrm{ha}$ can increase the growth of girth, number of leaves, and the number of fruit per plot. Litter compost fertilizer dose of $100 \mathrm{~kg} \mathrm{~N} /$ ha can promote the growth and production of red okra. Pruning treatment can increase the production of red okra.

Keywords : red okra, compost, leaf, pruning.
\end{abstract}

\begin{abstract}
ABSTRAK
Penelitian bertujuan untuk mengkaji interaksi antara dosis pupuk kompos serasah yang berbeda terhadap pertumbuhan dan produksi okra merah. Rancangan Penelitian yang digunakan adalah rancangan dasar acak lengkap pola faktorial $4 \times 2$ dengan tiga kali ulangan, faktor pertama yaitu dosis pupuk kompos serasah $\mathrm{K}(0,50,100,150 \mathrm{Kg} \mathrm{N} / \mathrm{ha})$. Faktor kedua adalah pemangkasan $\mathrm{P}$ (Tidak dipangkas dan dipangkas), setiap perlakuan diulang sebanyak tiga kali. Parameter yang diamati adalah lingkar batang, jumlah daun, berat buah per petak, jumlah buah per petak dan jumlah buah per tanaman. Data di analisis ragam dan dilanjutkan dengan Duncan's Multiple Range Test (DMRT). Hasil penelitian menunjukkan bahwa tidak terdapat pengaruh interaksi pada perlakuan dosis pupuk kompos serasah dan pemangkasan. Perlakuan dosis pupuk kompos serasah $50 \mathrm{Kg} \mathrm{N} / \mathrm{ha}$ dapat meningkatkan pertumbuhan lingkar batang, jumlah daun, dan jumlah buah per petak. Dosis pupuk kompos serasah $100 \mathrm{~kg}$ N/ha dapat meningkatkan pertumbuhan dan produksi okra merah. Perlakuan pemangkasan dapat meningkatkan produksi okra merah.
\end{abstract}

Kata kunci : Okra merah, pupuk kompos, serasah daun, pemangkasan.

\section{PENDAHULUAN}

Peningkatan produksi sayuran sangat perlu ditingkatkan untuk kepentingan kesehatan masyarakat di Indonesia. Sangat banyak macam sayuran yang dapat dibudidayakan di Indonesia termasuk tanaman okra merah (Albemoschus esculentus L. Moench). Okra merah adalah sayuran yang tinggi akan serat dan baik dikonsumsi masyarakat. Buah okra mempunyai kandungan gizi yang cukup tinggi, setiap 100 gram buah muda okra mengandung 33 kalori, 7 gr 
karbohidrat, 3,2 g serat dan $81 \mathrm{mg}$ kalsium (Lim dkk., 2012). Okra merah (Abelmoschus esculentus L. Moench) merupakan buah yang kaya akan vitamin $\mathrm{A}$ dan $\mathrm{C}$ serta mineral seperti $\mathrm{Ca}, \mathrm{Mg}$, dan Fe (Khare dan Sharma, 2015).

Pertumbuhan tanaman okra merah dapat dipengaruhi oleh beberapa faktor, antara lain pemberian pupuk organik. Pemberian pupuk pada tanaman dapat mengakibatkan peningkatan pertumbuhan dan produksi tanaman. Dosis pupuk $\mathrm{N}$ dapat meningkatkan jumlah daun, tinggi tanaman, dan berat segar polong (Uka dkk., 2013). Pertumbuhan vegetatif tanaman okra dapat dipengaruhi oleh pupuk $\mathrm{N}$ yang diaplikasikan, sehingga ketersediaan nutrisi yang dibutuhkan dalam masa pertumbuhan sudah tercukupi akibat pengaplikasian pupuk organik (Tiamiyu dkk., 2012).

Pupuk kompos merupakan pupuk yang terbuat dari sisa tanaman, sampah rumah tangga, dan limbah bahan organik lainnya. Pupuk kompos memiliki manfaat sebagai zat utama yang dapat membantu pertumbuhan dan produksi tanaman. Bahan yang dibutuhkan dalam pembuatan pupuk kompos dapat didapatkan dari limbah sekitar dan memiliki nilai jual yang tinggi (Wignjopranoto dkk., 2015). Kandungan kimia dari tanaman okra diantaranya adalah selulosa, hemiselulosa, lignin, pectin, lemak, lilin, dan ekstrak air masing masing sebesar 67,$5 ; 15,4 ; 7,1 ; 3,4 ; 3,9 ; 2,7 \%$. Pupuk kompos memiliki manfaat bagi tanah antara lain : dapat memperbaiki sifat dan struktur tanah, memperkaya mikroba tanah, meningkatkan unsur hara tanah, dan memiliki kemampuan daya serap air yang lebih baik (Suryati, 2014).

Pemangkasan atau yang biasa disebut dengan pemotongan paksa tanaman. Pemangkasan dilakukan dengan harapan untuk meningkatkan produksi panen. Tujuan dilakukan pemangkasan untuk mempercepat proses pembungaan dan merangsang tumbuhnya tunas-tunas produktif (Moniruzzaman dan Quamruzzaman, 2009). Pemangkasan sangat berpengaruh nyata terhadap pertumbuhan dan jumlah polong tanaman Okra (Nadira dkk., 2009). Perlakuan pemangkasan dapat mempengaruhi jumlah daun, diameter batang, proses pembungaan, cabang batang, berat basah polong berat kering polong, dan jumlah polong. Penelitian (Aliyu dkk., 2015) menyatakan bahwa proses pemangkasan dapat mempercepat proses pembungaan mencapai $50 \%$ lebih cepat dibandingkan dengan tanaman okra yang tidak dipangkas. Perlakuan pemangkasan dapat meminimalisir adanya Organisme Pengganggu Tanaman (OPT) (Iremiren, 1987).

\section{Materi}

\section{MATERI DAN METODE}

Penelitian telah dilaksakan pada bulan Maret sampai dengan Mei 2017 di Lahan dan Laboratorium Ekologi dan Produksi Tanaman, Fakultas Peternakan dan Pertanian Universitas Diponegoro. Pelaksanaan penelitian yang telah dilakukan meliputi persiapan, pemupukan dasar, penanaman, perawatan sampai panen okra .

\section{Metode}

Kegiatan yang dilakukan pada saat penelitian meliputi persiapan alat dan bahan, analisis (tanah, pukan sapi, dan kompos serasah) pengolahan tanah, pemupukan dasar, perlakuan pemupukan, pengukuran lubang tanam, penanaman, perawatan, pengamatan pertumbuhan tanaman, panen dan pengamatan produksi. Pengolahan tanah dan dilakukan pengukuran lahan dengan ukuran $3 \times 2 \mathrm{~m}$ sebanyak 24 petak. Pupuk kandang sapi yang digunakan sebagai pupuk dasar kemudian ditimbang, disebar dan diolah ke lahan dan didiamkan selama 2 minggu sebelum tanam.

Perlakuan dosis pemupukan dilakukan pada 1 minggu sebelum tanam. Pupuk kompos yang sudah ditimbang sesuai dosis kemudian disebar dan dicampur dengan tanah menurut pengacakan.

Seleksi benih dilakukan dengan merendam benih kedalam air kemudian dilakukan seleksi benih. Lahan yang sudah disiapkan kemudian dilakuan pengukuran jarak tanaman dan dilakukan penanaman. Penanaman benih dilakukan pada pagi hari, setiap lubang tanam diisi dengan benih sebanyak 3 benih per lubang tanam.

Pengamatan pertumbuhan dilakukan mulai 1 minggu setelah tanam (MST) sampai pada awal berbunga. Parameter pertumbuhan yang diamati adalah lingkar batang, jumlah daun. Parameter produksi yang diamati adalah jumlah buah per tanaman, jumlah buah per petak, dan berat buah per petak selama 1 bulan.

\section{Rancangan Percobaan dan Analisis Data}

Rancangan yang digunakan dalam penelitian 
ini adalah Rancangan Acak Lengkap (RAL) pola faktorial $4 \times 2$ dengan tiga kali ulangan. Faktor pertama adalah dosis pupuk kompos serasah $(\mathrm{K})$ $0,50,100$, dan $150 \mathrm{Kg} \mathrm{N} / \mathrm{ha}$. Faktor ke dua adalah pengaruh pemangkasan $(\mathrm{P})$ tidak dipangkas dan dipangkas. Analisis data dilakukan secara statistik berdasarkan prosedur analisis ragam (uji F). Apabila terdapat pengaruh yang nyata, maka dilanjutkan dengan Duncan's Multiple Range Test (DMRT) pada taraf 5\%.

\section{HASIL DAN PEMBAHASAN}

\section{Lingkar Batang}

Hasil analisis ragam menunjukkan bahwa tidak terdapat pengaruh interaksi antara perlakuan dosis pupuk kompos serasah dan pemangkasan terhadap lingkar batang tanaman. Perlakuan dosis pupuk kompos serasah dan pemangkasan masingmasing berpengaruh nyata $(\mathrm{P}<0,05)$ terhadap lingkar batang tanaman (Tabel 1).

Pemupukan kompos serasah meningkatkan lingkar batang okra merah. Semakin tinggi dosis yang lebih lama didalam tanah, sehingga kandungannya mampu meningkatkan perkembangan akar dan diameter batang okra (Atijegbe dkk., 2014).

Pengaruh pemangkasan memberikan hasil lingkar batang nyata lebih tinggi dibanding tanpa pemangkasan, uji DMRT menunjukkan hasil masing - masing sebesar 1,57 dan $1,45 \mathrm{~cm}$. Menurut Nadira dkk, (2009) perlakuan pemangkasan dapat meningkatkan pertumbuhan vegetatif tanaman okra, pemangkasan dapat menstimulir pertumbuhan vegetatif yaitu terbentuknya pertunasan dan perkembangan batang tanaman okra (Firoz dkk., 2011). Pemangkasan dapat memberikan cahaya yang optimal untuk pertumbuhan tanaman melalui proses fotosintesis, pembukaan stomata, dan sintesa klorofil, kemudian proses ini berdampak pada pembesaran dan diferensiasi sel yaitu pertumbuhan tinggi, perubahan ukuran dan stuktur dari batang maupun daun (Hasan, 2011).

\section{Jumlah Daun}

Tabel 1. Lingkar Batang Okra Merah pada Perlakuan Dosis Pemupukan Kompos Serasah yang Berbeda dan Pemangkasan

\begin{tabular}{|c|c|c|c|}
\hline \multirow{2}{*}{$\begin{array}{c}\text { Dosis pupuk kompos } \\
\text { serasah } \\
\text { (Kg N/ha) }\end{array}$} & \multicolumn{2}{|c|}{ Pemangkasan } & \multirow[b]{2}{*}{ Rata - rata } \\
\hline & Tidak dipangkas (P1) & Dipangkas (P2) & \\
\hline & \multicolumn{3}{|c|}{ - } \\
\hline $0(\mathrm{~K} 1)$ & 1,25 & 1,31 & $1,28^{\mathrm{d}}$ \\
\hline 50 (K2) & 1,35 & 1,46 & $1,40^{\mathrm{c}}$ \\
\hline $100(\mathrm{~K} 3)$ & 1,50 & 1,64 & $1,57^{\mathrm{b}}$ \\
\hline $150(\mathrm{~K} 4)$ & 1,69 & 1,88 & $1,79^{\mathrm{a}}$ \\
\hline Rata - rata & $1,45^{\mathrm{b}}$ & $1,57^{\mathrm{a}}$ & \\
\hline
\end{tabular}

Keterangan: Angka diikuti huruf berbeda pada kolom atau baris rata-rata menunjukkan berbeda nyata dengan uji DMRT 5\%

kompos serasah yang diberikan semakin tinggi lingkar batang. Hal tersebut disebabkan karena kandungan $\mathrm{N}$ merupakan penunjang utama pada masa pertumbuhan vegetatif tanaman sehingga pemakaian sampai $150 \mathrm{~kg} \mathrm{~N} / \mathrm{ha}$ memberi kenaikan pada lingkar batang okra. Pupuk organik dapat memberikan pengaruh yang nyata pada pertumbuhan vegetatif tanaman, (Ichsan dkk., 2015). Kandungan unsur hara pada pupuk organik dilepaskan lebih lambat dan disimpan untuk waktu
Hasil analisis ragam menunjukkan bahwa tidak terdapat pengaruh interaksi antara perlakuan dosis pupuk kompos serasah dan pemangkasan terhadap jumlah daun. Perlakuan dosis pupuk kompos serasah dan pemangkasan masing-masing berpengaruh nyata $(\mathrm{P}<0,05)$ terhadap jumlah daun (Tabel 2).

Pemupukan kompos serasah dapat meningkatkan jumlah daun okra merah. Semakin tinggi dosis kompos serasah yang diberikan, maka 
Tabel 2. Jumlah Daun Okra Merah pada Perlakuan Dosis Pemupukan Kompos Serasah yang Berbeda dan Pemangkasan

\begin{tabular}{|c|c|c|c|}
\hline \multirow{2}{*}{$\begin{array}{c}\text { Dosis pupuk kompos } \\
\text { serasah } \\
(\mathrm{Kg} \mathrm{N} / \mathrm{ha})\end{array}$} & \multicolumn{2}{|c|}{ Pemangkasan } & \multirow[b]{2}{*}{ Rata - rata } \\
\hline & Tidak dipangkas (P1) & Dipangkas (P2) & \\
\hline & \multicolumn{2}{|c|}{ - } & \\
\hline $0(\mathrm{~K} 1)$ & 15,67 & 16,83 & $16,25^{\mathrm{d}}$ \\
\hline $50(\mathrm{~K} 2)$ & 17,31 & 18,09 & $17,70^{\mathrm{c}}$ \\
\hline $100(\mathrm{~K} 3)$ & 18,40 & 19,47 & $18,93^{\mathrm{b}}$ \\
\hline $150(\mathrm{~K} 4)$ & 19,76 & 21,12 & $20,44^{\mathrm{a}}$ \\
\hline Rata - rata & $17,78^{\mathrm{b}}$ & $18,88^{\mathrm{a}}$ & \\
\hline
\end{tabular}

Keterangan : Angka diikuti huruf berbeda pada kolom atau baris rata-rata menunjukkan berbeda nyata dengan uji DMRT 5\%

jumlah daun semakin meningkat. Peningkatan jumlah $\mathrm{N}$ yang diaplikasikan maka jumlah daun yang tumbuh semakin banyak. Kandungan $\mathrm{N}$ yang tinggi pada awal pertumbuhan memberikan dampak yang baik pada pada masa vegetatif, karena pupuk $\mathrm{N}$ sendiri memiliki peran dalam pembentukan klorofil, asam amino, lemak, enzim dan senyawa lain (Ichsan dkk., 2015). Kandungan unsur hara pada pupuk organik memiliki peran penting yang dapat membantu aktivitas fotosintesis untuk mendorong pertumbuhan akar dan batang tanama (John dkk., 2004)

Pengaruh pemangkasan terhadap jumlah daun okra menunjukkan bahwa perlakuan pemangkasan meningkatkan jumlah daun secara nyata lebih tinggi dibanding dengan perlakuan tanpa pemangkasan, uji lanjut DMRT menunjjukan hasil masing - masing 18,88 dan 17,78 helai Pemangkasan memiliki peran dalam pertumbuhan vegetatif tanaman seperti mempercepat pertumbuhan cabang batang yang tumbuh pada ketiak daun, sehingga dapat meningkatkan jumlah daun tanaman okra. Menurut Iremiren (1987) pemangkasan sangat membantu tanaman dalam hal fotosintesis, karena pemangkasan pada pucuk tanaman membantu sinar matahari kesuluruh tanaman sehingga proses fotosintesis lebih maksimal. Pemangkasan membantu tanaman okra untuk merangsang produksi dan pengembangan daun agar aktivitas fotosintesis berlangsung secara efisien (Aliyu, 2015).

\section{Jumlah Buah per Tanaman}

Hasil analisis ragam menunjukkan bahwa tidak terdapat pengaruh interaksi antara perlakuan dosis pupuk kompos serasah dan pemangkasan terhadap jumlah buah per tanaman. Perlakuan dosis pupuk kompos serasah dan pemangkasan masing-masing berpengaruh nyata $(\mathrm{P}<0,05)$ terhadap jumlah buah per tanaman (Tabel 3).

Pemupukan kompos serasah memberikan hasil jumlah buah per tanaman. Semakin tinggi dosis kompos serasah, maka semakin banyak buah yang dihasilkan per tanaman. Peningkatan dosis pupuk $\mathrm{N}$ berpengaruh dalam pertumbuhan vegetatif tanaman, salah satunya pertumbuhan cabang yang menjadi tempat munculnya calon buah sehingga menyebabkan peningkatan jumlah buah per tanaman (Baw, 2014). Pupuk organik sangat berpengaruh pada jumlah buah okra per tanaman sejumlah 84 buah per tanaman. Hal ini dikarenakan adanya kandungan unsur hara yang cukup sehingga dapat membantu tanaman dalam laju fotosintesis yang mengakibatkan peningkatan jumlah cabang dan jumlah polong yang dihasilkan tanaman (Attigah dkk., 2013).

Pengaruh pemangkasan tanaman dapat meningkatkan jumlah buah per tanaman, uji DMRT menunjukkan hasil masing - masing 12,75 dan 10,58 buah per tanaman. Sesuai dengan pendapat Oyewole (2014) menyatakan bahwa dengan perlakuan pemangkasan memiliki pengaruh yang signifikan pada jumlah polong, diameter, dan berat buah okra. Perlakuan pemangkasan dapat meningkatkan $20-30 \%$ 
Tabel 3. Jumlah Buah per Tanaman Okra Merah pada Perlakuan Dosis Pemupukan Kompos Serasah yang Berbeda dan Pemangkasan

\begin{tabular}{|c|c|c|c|}
\hline \multirow{2}{*}{$\begin{array}{c}\text { Dosis pupuk kompos } \\
\text { serasah } \\
(\mathrm{Kg} \mathrm{N} / \mathrm{ha}) \\
\end{array}$} & \multicolumn{2}{|c|}{ Pemangkasan } & \multirow{2}{*}{ Rata - rata } \\
\hline & Tidak dipangkas $(\mathrm{P} 1)$ & Dipangkas (P2) & \\
\hline & \multicolumn{2}{|c|}{---------------------- (buah/tanaman) ----- } & \\
\hline $0(\mathrm{~K} 1)$ & 6,33 & 7,67 & $7,00^{\mathrm{c}}$ \\
\hline $50(\mathrm{~K} 2)$ & 8,00 & 9,67 & $8,83^{\mathrm{c}}$ \\
\hline $100(\mathrm{~K} 3)$ & 12,67 & 14,33 & $13,50^{\mathrm{b}}$ \\
\hline $150(\mathrm{~K} 4)$ & 15,33 & 19,33 & $17,33^{\mathrm{a}}$ \\
\hline Rata - rata & $10,58^{\mathrm{b}}$ & $12,75^{\mathrm{a}}$ & \\
\hline
\end{tabular}

Keterangan: Angka diikuti huruf berbeda pada kolom atau baris rata-rata menunjukkan berbeda nyata dengan uji DMRT 5\%

jumlah buah yang dihasilkan tanaman (Olasantan dan Salau, 2008). Selain dapat meningkatkan produksi, pemangkasan juga dapat meminimalisir timbulnya hama dan penyakit pada tanaman (Nadira dkk., 2009)

\section{Jumlah Buah per Petak}

Hasil analisis ragam menunjukkan bahwa tidak terdapat interaksi antara perlakuan dosis pupuk kompos serasah dan pemangkasan terhadap jumlah buah per petak. Perlakuan dosis pupuk kompos serasah dan pemangkasan masing-masing berpengaruh nyata $(\mathrm{P}<0,05)$ terhadap jumlah buah per petak (Tabel 4).

Pemupukan kompos serasah meningkatkan jumlah buah per petak tanaman. Semakin tinggi dosis kompos serasah yang diberikan, maka jumlah buah yang dihasilkan semakin meningkat. Menurut Afe dan Oluleye (2017) bahwa dengan kandungan pupuk oganik 2,5 t/ha memberikan pengaruh nyata pada hasil panen okra dibandingkan dengan tanaman tanpa penggunaan pupuk $\mathrm{N}$ dan dibandingkan dengan dosis dibawahnya. Ketersediaan hara yang cukup mengakibatkan peningkatan jumlah buah yang optimum (Ichsan dkk., 2015). Kandungan nitrogen pada pupuk organik sangat tinggi sehingga berperan sebagai sumber energi yang dapat meningkatkan akvitas mikroorganisme tanah dalam penyediaan hara tanaman (Moniruzzaman dan Quamruzzaman, 2009).

Pengaruh pemangkasan memberikan hasil buah tertinggi pada jumlah buah per petak. Uji lanjut DMRT menunjukkan bahwa pemangkasan menghasilkan jumlah buah per petak yang berbeda nyata dibandingkan dengan yang tidak dipangkas sebesar 234,75 dibanding 210,75 buah per petak. Hal ini menunjukkan bahwa pemangkasan

Tabel 4. Jumlah Buah Okra Merah per Petak pada Perlakuan Dosis Pemupukan Kompos Serasah yang Berbeda dan Pemangkasan

\begin{tabular}{|c|c|c|c|}
\hline \multirow{2}{*}{$\begin{array}{c}\text { Dosis pupuk kompos } \\
\text { serasah } \\
(\mathrm{Kg} \mathrm{N} / \mathrm{ha})\end{array}$} & \multicolumn{2}{|c|}{ Pemangkasan } & \multirow{2}{*}{ Rata - rata } \\
\hline & Tidak dipangkas (P1) & Dipangkas (P2) & \\
\hline & \multicolumn{3}{|c|}{ 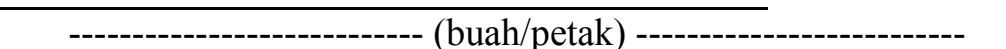 } \\
\hline $0(\mathrm{~K} 1)$ & 142,67 & 156,67 & $149,67^{\mathrm{d}}$ \\
\hline $50(\mathrm{~K} 2)$ & 173,67 & 195,00 & $184,33^{\mathrm{c}}$ \\
\hline $100(\mathrm{~K} 3)$ & 228,67 & 254,00 & $241,33^{b}$ \\
\hline $150(\mathrm{~K} 4)$ & 298,00 & 332,67 & $315,33^{\mathrm{a}}$ \\
\hline Rata - rata & $210,75^{\mathrm{b}}$ & $234,75^{\mathrm{a}}$ & \\
\hline
\end{tabular}

Keterangan : Angka diikuti huruf berbeda pada kolom atau baris rata-rata menunjukkan berbeda nyata dengan uji DMRT 5\% 
memiliki pengaruh sangat nyata terhadap produksi tanaman okra. Menurut Aliyu dkk. (2015) bahwa pemangkasan merangsang produksi daun untuk proses fotosintesis sehingga berpengaruh terhadap pertumbuhan dan jumlah buah okra. Polong pada okra dihasilkan dari bunga per tanaman, hal ini menunjukkan bahwa proses pembungaan yang cepat akibat pemangkasan memberikan pengaruh pada peningkatan jumlah polong (Olasantan dan Salau, 2008).

\section{Berat Buah per Petak}

Hasil analisis ragam menunjukkan bahwa tidak terdapat interaksi antara perlakuan dosis pupuk kompos serasah dan pemangkasan terhadap berat buah per petak. Perlakuan dosis pupuk kompos serasah dan pemangkasan masing-masing berpengaruh nyata $(\mathrm{P}<0,05)$ terhadap berat buah per petak (Tabel 5).

Pemupukan kompos serasah meningkatkan berat buah okra merah. Peningkatan berat buah juga dapat mempengaruhi jumlah polong yang dihasilkan semakin meningkat (Attigah dkk., 2013).

Pengaruh pemangkasan memberikan hasil berat buah per petak lebih tinggi dibandingkan dengan tanaman yang tidak dipangkas. Uji DMRT menunjukkan hasil masing - masing sebesar 7401,42 dan 5862,80 g. Pemangkasan memiliki peran yang dapat meningkatkan jumlah tunas, cabang baru, dan jumlah daun tanaman. Peningkatan jumlah daun dapat mempengaruhi hasil fotosintesis yang selanjutnya digunakan untuk proses pembungaan dan pembentukan buah. Menurut Aliyu dkk. (2015) bahwa perlakuan pemangkasan menghasilkan hasil terbaik dalam hal pertumbuhan dan produksi tanaman, dan meningkatkan berat polong okra. Pemangkasan dapat meningkatkan produksi dari $29 \%-36 \%$ dibandingkan dengan tanaman yang tidak dipangkas. Perlakuan pemangkasan sangat membantu tanaman untuk mendapatkan sinar

Tabel 5. Berat Buah per Petak Okra Merah pada Perlakuan Dosis Pemupukan Kompos Serasah yang Berbeda dan Pemangkasan

\begin{tabular}{cccc}
\hline \hline \multirow{2}{*}{$\begin{array}{c}\text { Dosis pupuk kompos } \\
\text { serasah } \\
(\mathrm{Kg} \mathrm{N} / \mathrm{ha})\end{array}$} & \multicolumn{2}{c}{ Pemangkasan } & Rata - rata \\
\cline { 2 - 3 } $0(\mathrm{~K} 1)$ & Tidak dipangkas (P1) & Dipangkas (P2) & \\
\hline $50(\mathrm{~K} 2)$ & 4139,48 & 6656,16 & $5398,82^{\mathrm{c}}$ \\
$100(\mathrm{~K} 3)$ & 5424,71 & 6688,07 & $6065,39^{\mathrm{bc}}$ \\
$150(\mathrm{~K} 4)$ & 6387,96 & 7275,61 & $6831,79^{\mathrm{b}}$ \\
Rata - rata & 7499,05 & 8983,84 & $8241,45^{\mathrm{a}}$ \\
\hline
\end{tabular}

Keterangan: Angka diikuti huruf berbeda pada kolom atau baris rera-rata menunjukkan berbeda nyata dengan uji DMRT $5 \%$

per petak dipengaruhi akibat peningkatan dosis kompos serasah yang diaplikasikan. Pemupukan dosis $\mathrm{N}$ dapat meningkatkan produksi buah per petak, dengan penggunaan dosis $\mathrm{N}$ sebanyak 125 $\mathrm{kg} \mathrm{N} /$ ha sampai $175 \mathrm{~kg} \mathrm{~N} / \mathrm{ha}$ (Moniruzzaman dan Quamruzzaman, 2009). Peningkatan fotosintesis yang tinggi dapat merangsang pertumbuhan cabang tanaman yang berakibat mempercepat proses pembungaan dan peningkatan berat polong tanaman okra. Pengaplikasian pupuk menghasilkan produksi yang lebih tinggi dibandingkan tanpa pemberian pupuk, selain itu matahari yang cukup (Olasantan dan Salau, 2008). Hasil produksi okra pada masa panen sangat signifikan pada tanaman yang dipangkas, hasil panen mencapai 16,4 t/ha (Firoz dkk., 2011).

\section{KESIMPULAN}

Kesimpulan dari penelitian yang telah dilaksanakan adalah dosis pupuk kompos serasah dan pemangkasan secara bersama - sama tidak mempengaruhi pertumbuhan dan produksi okra merah. Semakin tinggi dosis kompos serasah 
sampai $150 \mathrm{~kg} \mathrm{~N} /$ ha meningkatkan pertumbuhan dan produksi okra merah. Pemangkasan meningkatkan pertumbuhan dan produksi okra merah.

\section{DAFTAR PUSTAKA}

Afe A.I and F. Oluleye. 2017. Response of okra (Abelmuschus esculenthus L. Moench) to combined organic and inorganic foliar fertilizers. Int $J$ Recycl Org Waste Agricult . 189 - 193.

Aliyu, U., M. Sukuni., and L. Abu Bakar. 2015. Effect of pruning on growth and fresh fruit yield of okra (Abelmochus esculentus L. Moench). Department of Crop Science. Nigeria. 7 (4) : 2636 - 2640.

Attigah, S.A., E.K. Asiedu., K. Agyarko, and H.K, Dapaah., 2013. Growth and yield of okra (Abelmoschus esculentus L.) as affected by organic and inorganic fertilizers. ARPN Journal of Agricultural and Biological Science. 12(8) : $766-770$.

Atijegbe, S.R., B.O. Nuga., N. E.S. Lale., and R.N. Osayi. 2014. Effect of organic and inorganic fertilizer on okra (Abelmoschus esculentus L. Moench) production and incidience of insect pets in the humid tropics. IOSR Journal of Agriculture and Veterinary Science. 7 (9) : 25-30.

Baw, A.O. 2014. Effects of plant density and nitrogen fertilization on vegetative growth, seed yield and quality of okra plants. Alandalus For Soc. Appl. Sci. 2(4) : $43-$ 57.

Firoz, Z.A., M.H. Rashid, and M.S. Huda. 2011. Effect of alley size and hedgerow pruning interval on phenology and yield of okra (Abelmoschus esculentus (L.) Moench) in hill slope. Bangladesh J. Agril. Res. 36(1) : 143-150.

Hasan, Z. 2001. Pengaruh beberapa cara pemangkasan tajuk terhadap pertumbuhan dan produksi gambir (Uncaria gambir
(Hunter) Roxb). Jurnal Litri. 7 (4): 120 123.

Ichsan, C.M., P. Rikiyandika., dan I. Wijaya. 2015. Respon produktifitas okra (Abelmoschus eschulentus) terhadap pemberian dosis pupuk petroganik dan pupuk N. Agritrop Jurnal Ilmu Pertanian. $29-41$.

Iremiren, G.O. 1987. Effect of artificial defoliation on the growth and yield of okra (Abelmoschus esculentus). Expl Agric. 1 7.

John. L.W., D.B. Jamer., L.T. Samuel, and L.W. Warmer. 2004. Soil and fertilizer and introduction to nutrient management. India.

Khare, C.P., and N.D. Sharma. 2015. Fungal diseases of okra (Abelmoschus esculentus L.) and their intgated management. Springer. India.

Lim, V., B.S.K., Leonardus, dan K. Natania. 2012. Studi karakteristik dan stabilitas pengemulsi dari bubuk lender okra (Abelmoschus esculentus). Jurnal Aplikasi Teknologi Pangan. 4 (3).

Moniruzzaman, M., and A.K.M. Quamruzzaman. 2009. Effect of nitrogen levels and picking of green fruits on the fruits and seed production of okra (Abelmoschus esculentus (L.) Moench). J. Agric Rural. Bangladesh. $99-106$.

Nadira, S., B. Hatidjah, dan Nuraeni. 2009. Pertumbuhan dan hasil tanaman Okra (Abelmoschus esculenthus) pada perlakuan pupuk dekaform dan pemangkasan. J Agrisains. 10(1) : $10-15$.

Olasantan, F.O, and A.W. Salau. 2008. Effect of pruning on growth, leaf yield and pod yields of okra (Abelmoscus esculentus (L.) Moench). Journal of Agricultural Science. $146(1): 93-102$.

Oyewole, C.I. 2014. Varying levels and stage of leaf harvest implication for okra (Abelmoschus esculentus (L.) Moench) 
growth, development and yield. Research Journal of Agriculture and Environmental Management. 3(3) : 184-188.

Suryati, T. 2014. Bebas Sampah Dari Rumah. PT. Agromedia Pustaka. Jakarta.

Tiamiyu, R.A., H.G., Ahmed., and A.S., Muhammad. 2012. Effect of sources of organic manure on growth and yields of okra (Abelmoschus esculentus (L.) Moenc). Journal of Basic and Applied
Science. Nigeria. 20(3) : $213-216$.

Uka, U.N., K.S. Chukwuka., and M. Iwuagwu. 2013. Relative effect of organic and inorganic fertilizer on the growth of okra (Abelmoschus esculentus (L.) Moench). Journal of Agricultural Sciences. 3(58) : $159-166$

Wignjopranoto, J., S. Raharjo, dan T.A. Kuncoro. 2015. Rumah Organik. PT. Agromedia Pustaka. Jakarta. 